\title{
Taking care to protect the environment against damage: a meaningless obligation?
}

\section{Karen Hulme}

Karen Hulme is a senior lecturer in the Law School at the University of Essex, UK.

\section{Abstract}

Little attention is paid to the obligation of 'care' in Article 55(1) of Additional Protocol I. Beyond a general principle of upholding environmental value in times of armed conflict, what is the scope and content of the obligation? If it is worthless, what makes it so? Since the care provision includes the same high threshold of harm found elsewhere in the environmental provisions, has this stumbling block now been removed by state practice? Rule 44 of the Customary Law Study might appear to suggest that this is so, or does it? Ultimately then, is the care obligation worth caring about?

Concern for the environment has vastly increased over the past fifty years or so, and particularly so in the past ten years, undoubtedly a reaction to constant media attention focussed on climate change. ${ }^{1}$ As a consequence, environmental concern has crossed over from pure environmental law into most areas of law. Law-makers working in areas of aid and development, human rights, international trade, company law, discrimination, refugee law, space law, and law of the sea, for example, have all had to consider the environment, both in terms of the impact of those activities on the environment and, vice versa, the impact of environmental degradation - most urgently as the result of climate change - on those activities. This integration of environmental concern into almost every aspect of everyday life serves to educate the world's population about the fragility of our environment, and about the need for its careful governance. Meanwhile, the laws of armed 
conflict have recognized the need for environmental protection for over three decades now and there is some evidence that the main treaty provisions, or at least some aspects of them, have achieved a customary law equivalent. ${ }^{2}$

While the two provisions in Additional Protocol I ${ }^{3}$ (Articles 35(3) and 55) have certainly directed attention to the notion of environmental protection in times of armed conflict, it is suggested that the real gem hidden among those provisions is not the prohibition of means and methods causing widespread, longterm, and severe damage in Article 35(3) of Protocol I, but the obligation on states parties to take 'care' to protect the environment against such harm.

Having been largely ignored for decades, the provision - or at least debate surrounding the provision - has received new life from the authors of Customary International Humanitarian Law (hereafter Customary Law Study). There is a difference in format, but the main question to be asked of the opening sentence of the Study's Rule 44 is whether its substance retains the same 'care' obligation as that of Article 55(1) of Protocol I or if it represents a new departure. Furthermore, an analysis of the 'care' obligation suggests that it might be useful in protecting the wartime environment from other emergent threats, such as the pollution released in attacks on chemical, pharmaceutical, and oil facilities, the destruction and exploitation of conflict resources, and the polluting effects of certain weapons. Might it also be valuable in preventing military actions exacerbating the onset or impacts of climate change?

\section{A valued environment}

The question is often raised of why Protocol I contains two provisions (Articles 35(3) and 55(1)) that on first inspection appear to cover the same ground. ${ }^{4}$ The general response is that, while there is some overlap in the language of Articles 35(3) and 55(1), the two provisions are different in emphasis. ${ }^{5}$ Article 35(3) of Protocol I sits neatly beside the most fundamental provisions on means and methods, and its placing here is pertinent to the absolute limit that it imposes. This section of the Protocol is not limited by the reference in Article 49(3) to warfare having effects on land, and so it appears to apply to all the Earth's environment, including the marine environment and areas beyond national jurisdiction. The repetition of language in the second sentence of Article 55(1) of Protocol I but with

1 See Intergovernmental Panel on Climate Change, Climate Change 2007: The Physical Science Basis, Cambridge University Press, Cambridge, 2007.

2 Jean-Marie Henckaerts and Louise Doswald-Beck, Customary International Humanitarian Law, Cambridge University Press, Cambridge, 2005 (hereafter Customary Law Study), Commentary and evidence for Rules 43-45.

3 Protocol Additional to the Geneva Conventions of 12 August 1949, and Relating to the Protection of Victims of International Armed Conflicts (Protocol I), of 8 June 1977 (hereafter Protocol I).

4 Yves Sandoz, Christophe Swinarski, and Bruno Zimmerman (eds), Commentary on the Additional Protocols of 8 June 1977 to the Geneva Conventions of 12 August 1949, ICRC/Martinus Nijhoff Publishers, Geneva, 1987, paras. 1449-1452.

5 Ibid., para. 2133. 
the additional requirement of risk to the human population reminds us why the prohibition exists. The prohibition repeats mention of means and methods causing such harm, but it is indicated as being only an example of the notion of protection elaborated in the first sentence of Article 55(1). It is to this frequently overlooked first sentence of Article 55(1), however, that we must turn our attention.

The opening sentence of Article 55(1) of Protocol I stipulates that 'Care shall be taken in warfare to protect the natural environment against widespread, long-term and severe damage'. This first sentence thus encapsulates the raison d'être or what Dinstein referred to as the 'underlying concept' of the provision. ${ }^{6}$ According to Cohan, the 'care clause' suggests a 'supervening standard or a general governing principle of due care in military deployments. That is, it seems to require that the effects or repercussions of permitted deployments ... do not end up escalating or otherwise producing the prohibited effects. ${ }^{77}$ In simple and clear terms it suggests the need to protect the environment in times of armed conflict. And, unlike the second sentence, the 'care' obligation does not refer to environmental protection only on those occasions when people might be harmed. ${ }^{8}$ Yet is that all that this first sentence does? Does it function only as the 'underlying concept', and, if so, what does this mean in practice?

Certainly, without this first sentence the rest of the provision together with Articles 35(3) and 36 of Protocol I would be sufficient to continue the ban on means and methods of warfare causing widespread, long-term, and severe environmental damage. These other provision parts would also be capable of indicating the recognition of the need to protect the environment in armed conflict, as well as why it is protected. Is this first sentence then simply superfluous? Indeed, according to the ICRC Commentary, 'To some extent this formula [found in the first sentence] seems to reduce the effect of the provision by allowing some latitude of judgment'. ' Consequently, does the first sentence in fact weaken the provision? On the contrary, it will be argued, this obligation of 'care' is a key strength of Protocol I for those engaged in the pursuit of environmental protection. The provision recognizes the value of the environment to humanity; that the environment is so important that its value can limit the actions of parties to armed conflict. The first sentence of Article 55(1) is thus a lasting reminder of this recognition that humankind must continue to protect the environment in armed conflict.

While the provision, or indeed any other provision, does not explicitly designate the environment as civilian in nature, this is the prevailing view of

6 Yoram Dinstein, 'Protection of the environment in international armed conflict', in Max Planck Yearbook of United Nations Law, Vol. 5, 2001, p. 531.

7 John A. Cohan, 'Modes of warfare and evolving standards of environmental protection under the international law of war', in Florida Journal of International Law, Vol. 15, 2003, p. 504.

8 Much confusion often surrounds the notion of 'anthropocentrism'; there is a difference, however, between why we choose to protect the environment (which is arguably anthropocentric, as that protection is ultimately based on the benefit of a viable environment to humanity) and what we choose to protect (for example, prohibiting 'pure' environmental damage in the sense that no people are harmed).

9 Y. Sandoz et al., above note 4, para. 2133. 
the international community and undoubtedly the force behind the protection. Article 55 of Protocol I is positioned within Part IV, Section I, Chapter III, entitled 'Civilian objects', which contains the general protection of civilian objects as well as other provisions concerning protection of civilian objects when used by the military: notably Article 54, concerning 'objects indispensable to the survival of the civilian population', and Article 56, governing the 'protection of works and installations containing dangerous forces'. This is not to suggest that the environment or a specific component of it cannot form a legitimate military objective, but the general view is that unless the environment (or a part of it) fulfils the definition provided by Article 52(2) of Protocol I it should be considered as prima facie civilian. Certainly, the recognition of the environment as a prima facie civilian object has done more to protect it than any environmentally specific rule of international humanitarian law. And, it is submitted, that recognition is embodied in the first sentence of Article 55(1). Once the notion of the 'environment' is given form and content by this recognition of civilian status, it becomes a real thing or entity that is to be saved from harm. Once rivers, lakes, and trees are seen as prima facie civilian, they are no longer just a valueless part of the scenery in which a battle takes place. And over the years, as we have come to realize our human impact on the environment as well as our dependence on it and its viability, it seems that the laws of war - or at least the ways in which they are applied - have generally and genuinely become greener. Of course, flowing from the recognition of civilian status is the invaluable protection granted by the principles of distinction ${ }^{10}$ and proportionality, ${ }^{11}$ as well as those provisions governing the required precautions in attack $^{12}$ and against the effects of attack. ${ }^{13}$

Moving beyond the civilian-based protection afforded by Article 55(1), what is meant by the obligation requiring parties to take care to protect the environment?

\section{The notion of 'care'}

The term 'care' itself is not unusual in international humanitarian law; it is frequently used in the sense of providing medical care to the wounded and sick ${ }^{14}$ or care for children. ${ }^{15}$ The obligation of providing children with the 'care and aid they

10 See Protocol I, Art. 48.

11 See Protocol I, Art. 51(5)(b).

12 See Protocol I, Art. 57.

13 See Protocol I, Art. 58.

14 See, for example, Geneva Convention for the Amelioration of the Condition of the Wounded and Sick in Armed Forces in the Field of August 12, 1949, Arts. 12 and 15; Geneva Convention Relative to the Treatment of Prisoners of War of August 12, 1949, Art. 30; Geneva Convention Relative to the Protection of Civilian Persons in Time of War of August 12, 1949, Arts. 18 and 50.

15 See, for example, Convention on the Prohibition of the Use, Stockpiling, Production and Transfer of Anti-Personnel Mines and on their Destruction of 18 September 1997 (hereafter Anti-Personnel Mines Convention), Art. 6(3) and Protocol on Explosive Remnants of War (Protocol V to the 1980 UN Certain Conventional Weapons Convention) of 28 November 2003, Art. 8(2), both concerned with 'care and 
require', ${ }^{16}$ for example, appears to be slightly more akin to a needs-based, parental, nurturing role. When examining the obligation of taking 'care' in Article 55(1), however, this same sense of nurturing is not immediately apparent. Taking care to prevent some occurrence or injury, for instance, is a different usage of the notion of care and appears to be more akin to an obligation of ensuring that one employs 'caution' and pays 'attention' to the need to avoid such injury. ${ }^{17}$ The Netherlands' Military Manual (1993), for example, requires that 'attention must be paid to the protection $^{18}$ of the environment against widespread, long-term, and severe damage, and the Swedish Manual (1991) directs that 'the parties shall exercise caution' so that widespread, long-term, and severe damage to the environment 'can be avoided'. ${ }^{19}$ Consequently, the notion of 'care' found in Article 55(1) is one of approaching the issue with caution and attention, just as one might say, for instance, that there is a need to 'take care' when crossing the road, or to pay attention or be cautious when crossing the road, or to take steps to ensure that you cross the road safely.

Furthermore, the obligation of 'constant care' found in Article 57 of Protocol I governing precautions in attack would seem to suggest an ongoing or more integral duty of paying attention or heed to a particular issue while engaging in, in this case, military operations: to pay heed to constantly or to be borne in mind constantly. The Customary Law Study adds further descriptors in the sense of 'particular care' and 'special care'. ${ }^{20}$ And so it would seem that 'care' alone (that is, without the descriptor) denotes a somewhat lower scale or standard of caution. Consequently, if the required standard of care varies with the importance or value of the protected object, how much 'care' needs to be provided to the environment to fulfil the obligation in Article 55(1) of Protocol I and what is the content of the obligation of 'care'?

\section{'Taking care to protect'}

\section{The nature of the obligation of 'care'}

However one analyses Article 55(1) of Protocol I it is difficult to conclude that it is anything other than an obligation of conduct rather than result. This conclusion follows from the absence of any notion of 'ensuring' such protection. Of course, the all important word 'shall' is also included, which makes this a course of conduct that states parties must undertake. And reference to the notion of

rehabilitation, and social and economic reintegration, of mine victims'; Convention on Cluster Munitions of 30 May 2008, Art. 5(1), concerned with 'medical care'.

16 See Protocol I, Art. 77(1).

17 See also Anti-Personnel Mines Convention, above note 15, Art. 8(2); and 2008 Convention on Cluster Munitions, Art. 8(2), stating that 'care being taken to avoid abuse' of the clarification mechanism.

18 See J. M. Henckaerts and L. Doswald-Beck, above note 2, Vol. II, Part 1, Ch. 14, p. 881, para. 177.

19 Ibid., p. 882, para. 181.

20 See ibid., Vol. I, Rules 42, 81, and 84 on 'particular care', and Rule 38 for 'special care'. 
'warfare ${ }^{21}$ would appear to relate the obligation to all parties engaged in operations (that is, in both attack and defence). Consequently, the obligation is one of 'taking steps', in attack and defence, to protect the environment, often referred to in shorthand as an obligation of 'due diligence'. ${ }^{22}$ In answering the question of what steps need to be taken to show 'due diligence', environmental law typically requires only 'reasonable ${ }^{23}$ steps, and there is no reason to suggest that this would not also be appropriate for the 'care' obligation in Article 55(1). Finally, the inclusion of a very high threshold of harm in that provision thus suggests that 'reasonable steps must be taken to avoid widespread, long-term and severe environmental damage'.

\section{The notion of environmental 'protection'}

In environmental law, the notion of environmental 'protection' tends to be an umbrella notion for the wide range of environmentally beneficial obligations that states must undertake. Obligations, for example, that range from simple 'prevention' of damage or pollution by requiring the prohibition of certain activities or by minimizing their impacts, to the more onerous 'conservation' and 'wise use' of natural resources (biotic and abiotic). Most of these methods of environmental protection are not fundamentally incompatible with military operations: for example, banning a particular substance or activity altogether or in a particular location, or otherwise reducing the environmental (or human) impact of activities. The more onerous obligations found in environmental treaties, however, might be incompatible. For instance, we cannot expect those engaged in hostilities to create conservation projects for endangered species - for example, to set up a breeding programme, or purposely to flood an area to create a wetland rich in biodiversity and to manage it sustainably on a stewardship basis. We can, however, require a level of protection of these established activities in wartime, largely by avoiding or minimizing the impact of the conflict in their vicinity. Indeed, international humanitarian law may already include recognition of such methods of protection. For example, states could utilize the notion of demilitarized zones, ${ }^{24}$ which, although established to protect the civilian population, ${ }^{25}$ could conceivably be used to protect the environment provided the requirements of the provision are met. Michael Bothe utilizes a similar methodology in his suggestion of a new rule designed to protect certain environmental spaces..$^{26}$ At present, provided that these

21 The meaning of 'warfare' appears to relate to active hostilities, certainly to the use of means and methods of warfare, and, according to the ICRC Commentary, is apparently broader than 'combat'. See Y. Sandoz et al., above note 4, para. 1401 .

22 See Karen Hulme, War Torn Environment: Interpreting the Legal Threshold, Martinus Nijhoff, Leiden, 2004, pp. 80-88; René Lefeber, Transboundary Environmental Interference and the Origin of State Liability, Kluwer Law International, The Hague, 1996, pp. 61ff.

23 R. Lefeber, above note 22.

24 See Protocol I, Art. 60.

25 Y. Sandoz et al., above note 4, paras. 2303 and 2312.

26 Michael Bothe, 'War and Environment', in R. Bernhardt (ed), Encyclopedia of Public International Law, Vol. 4, Elsevier, Amsterdam, 2000, p. 1344. Note that draft Article 48 ter, concerned with the protection 
spaces do not become (legitimate) military objectives, their protection depends largely on a rigorous application of the proportionality rule and, it is suggested, the 'care' obligation, with the latter also functioning as a brake on the means and methods of attack of nearby targets. Clearly, therefore, while it is often not the methods themselves that are alien to international humanitarian law, it is generally the level of protection that can be afforded the environment during armed conflict that is the real issue.

Thus, the obligation of 'protection' in Article 55(1) would seem to suggest that states parties must take steps - positive steps - to 'guard', 'defend', 'keep safe' the environment from damage. While a guardianship or stewardship role would provide the highest level of environmental protection, in practice the protection that can be afforded will largely entail minimizing collateral impacts and guarding against the higher levels of harm. As a rule of thumb, more serious harm will clearly be caused more easily and quickly to the more important environmental areas or components, such as areas rich in biodiversity and fragile environments. In theory, therefore, in regard to such fragile or important environmental components, the standard of 'care' (for fulfilment of the 'care' obligation) would require greater cautionary measures.

\section{Practical applications of environmental 'care'}

The obligation of protection more generally could therefore include a wide range of actions, including (but not limited to): (a) undertaking a rigorous environmental assessment involving a thorough investigation of intellience data and evaluation of potential environmental harm of a particular attack scenario, including a full appraisal of the environmental effects (including synergistic effects) of proposed weapons, as well as risks to particular kinds of environment; ${ }^{27}$ (b) the alteration of an attack scenario to avoid potential environmental harm; and (c) calling off a planned attack due to the potential environmental harm. All of these scenarios would appear to fit the definition of 'taking care to protect the environment against damage'. There is no doubt that more basic actions are also within the definition.

Returning to the question of how much care is needed for fulfilment of the obligation: what is the minimum that states must do? A good faith application of the obligation would surely entail much more than a simple 'tick box' approach: it would require a proper environmental assessment in the circumstances of potential harm. Where environmental harm was identified as a potential consequence of an action, the mandatory obligation to 'take steps to protect the environment' against

of 'nature reserves', was rejected for inclusion in Protocol I. See Y. Sandoz et al., above note 4, paras. 2138-9 and proposed Amendment CDDH/III/276.

27 For the obligation of states to take the environment into consideration in their weapons assessment, see International Committee of the Red Cross, A Guide to the Legal Review of New Weapons, Means and Methods of Warfare: Measures to Implement Article 36 of Additional Protocol I of 1977, ICRC, Geneva, 2006, pp. 19-20. 
that damage would then surely require the state party not only simply to 'consider' how it could prevent that damage but to take positive steps if needs be to avoid or reduce the potential damage (moving from actions (a) through to (b) and (c) above). This could be done, for example, by actions of the attacking party in minimizing the weaponry necessary for the attack, employing different weaponry or tactics from those planned, changing the objective to be attacked, ${ }^{28}$ or changing the timing of the attack, and ultimately, of course, by calling off the attack. Depending on the level of military advantage to be gained this last suggestion might not be so extreme in the circumstances. The defending party also has an obligation of 'care' in warfare, which includes minimizing the risks to its environment, including its particularly rare, endangered, biodiverse, and fragile environments. This obligation could include the removal of military objectives from the vicinity of its national parks or similarly important environmental areas, and could also include the closure of particularly risky or sensitive chemical facilities. ${ }^{29}$ During the Kosovo Conflict, for example, the operators of some facilities attempted to remove or make safe hazardous chemicals on site, so that if attacked the damage would be minimized. ${ }^{30}$ Clearly, a strict application of military necessity and proportionality might also reduce the number and types of chemical facilities attacked.

\section{The threshold for 'care'?}

The application of the 'care' obligation in Article 55(1) of Protocol I is, of course, limited to preventing, or 'taking steps' to prevent, environmental damage only where that damage might reach the threshold scale of widespread, long-term, and severe harm. The inclusion of the threshold undoubtedly reduces the value of the 'care' obligation; some might say its value is reduced to zero. Indeed, the carrying out of an assessment of potential environmental harm will probably be sufficient fulfilment of the obligation, provided that the assessment reveals a level of potential harm below the threshold. And, as will be seen, even the most devastating, irreversible destruction of an area of environment will fail to breach the threefold threshold if it is insufficiently 'widespread'. Consequently, the threshold of damage required to activate the obligation remains its fundamental hurdle to robustness. So, what if the threshold of 'widespread, long-term and severe' damage could be lowered or, better still, removed altogether?

28 This obligation is also recognized in part in Protocol I, Art. 57(3).

29 These obligations can be deduced from both Articles 55 and 58 of Protocol I.

30 Unfortunately, in the example of the Azotara fertilizer plant, the reports suggest that workers dumped 250 tons of liquid ammonia into the Danube, apparently fearing that greater environmental damage would be caused if the plant were bombed and the ammonia set on fire: see United Nations Environment Programme and United Nations Centre for Human Settlements (Habitats), The Kosovo Conflict: Consequences for the Environment and Human Settlements, UNEP and UNCHS, Geneva, 1999, p. 35. 


\section{The threshold: a 'credible' interpretation}

While better scientific understanding today helps us to realize more starkly how easily damage can be caused to the environment, there is little evidence of any real downward movement in the way in which the three terms of Article 55(1) of Protocol I are interpreted. Rather obviously, the US Operational Law Handbook suggests that (in theory) the 'severe' element of the threshold might 'possibly' have been met by the two nuclear bombs dropped on Japan during World War II, ${ }^{31}$ although it is worth remembering that the US, among others, rejected the applicability of Articles 35(3) and 55 of Protocol I to the use of nuclear weapons. ${ }^{32}$ Consequently, it seems that the only weapon that the US can foresee might breach the threshold is the one weapon that it denies applicability to. Would a more modern, environmentally educated approach to the threshold of 'severe' harm, therefore, lead us to quantify as 'severe' harm that which would not have been so quantified previously? And, naturally, therefore, is the threshold of 'severe' harm constantly being lowered in real terms as we become better able to assess the true scale and quantification of harm to the environment?

Regardless, the real obstacle to lowering the threshold lies with the term 'widespread'. Even with the apparent endorsement of the definition provided in the Annex to the Convention on the Prohibition of Military or any Hostile Use of Environmental Modification Techniques (ENMOD) of 'several hundred square kilometres ${ }^{33}$ as a 'credible interpretation' by the US in recent years, ${ }^{34}$ it still means that an area the size of the New Forest in the UK (measuring approximately 377 square kilometres), ${ }^{35}$ or even a whole country (for example, the Maldives, measuring 300 square kilometres), would need to be damaged, in addition to the fulfilment of the other two threshold criteria ('long-term' and 'severe'). Quite straightforwardly, one can imagine 'severe' harm that is at the same time also

31 See Brian Bill, Marie Anderson, and J. Jeremy Marsh (eds), Operational Law Handbook 2009, International and Operational Law Department, Judge Advocate General's Legal Center and School, Charlottesville, VA, 2009 (hereafter US Operational Law Handbook), p. 351, available at: https://www. jagcnet.army.mil/JAGCNETPortals/Internet/DocLibs/kflddoclib.nsf/f45bab0efc3ec172852574d00068d6a5/ 23842DE37A0862CF852576E7004B669E/\$FILE/2009\%20operational-law-handbook.pdf (last visited 20 September 2010). On the definition of 'severe', the US Operational Law Handbook refers to 'any act that prejudices the health or survival of the population', suggesting 'roughly the same meaning' as that used in the Convention on the Prohibition of Military or Any Hostile Use of Environmental Modification Techniques (ENMOD) of 10 December 1976; namely, 'severe or significant disruption or harm to human life, natural or economic resources, or other assets'. See Annex to the ENMOD Convention, Understandings regarding the Convention, letter c). See also Paul Fauteux, 'The Gulf War, The ENMOD Convention and the Review Conference', in UN Institute for Disarmament Research Newsletter, Vol. 18, 1992, p. 6.

32 See the statement by the US in Adam Roberts and Richard Guelff, Documents on the Laws of War, Clarendon Press, Oxford, 3rd edition, 2000, p. 512; note the reservation of the UK, for example, available at: http://www.icrc.org/ihl.nsf/NORM/0A9E03F0F2EE757CC1256402003FB6D2?OpenDocument (last visited 20 September 2010).

33 See Annex to the ENMOD Convention, Understandings regarding the Convention, letter a).

34 See US Operational Law Handbook, above note 31, p. 351.

35 See 'New Forest: explorers' guide', available at: http://www.newforestexplorersguide.co.uk/sitefolders/ landscape/aintroduction/landscapeintropage.html (last visited 20 September 2010). 
anticipated to be 'long-term'; ${ }^{36}$ indeed, it is probably definable as 'severe' because of that very anticipation. Yet not all 'long-term' and 'severe' harm will be 'widespread', and not all 'widespread' harm will be either 'long-term' or 'severe'. Certainly, 'widespread' environmental damage could be classifiable as 'significant' or 'serious' damage without more, but if there is no foreseeable 'long-term' harm then it is also unlikely to be classified as 'severe'.

Other than this 'credible' interpretation of 'widespread' damage there appears to be little evidence that states have changed their perceptions of the scale required for the three threshold terms.

\section{Omitting the threshold}

Ultimately, it is the enduring immensity of the threshold that proves to be the provision's downfall. It might seem like an unlikely suggestion, therefore, but can we then simply omit the threshold? Upon first glance, this is precisely what the authors of the Customary Law Study appear to have done with their Rule 44.

\section{Analysing Rule 44}

In the Customary Law Study, Rule 45 reflects the prohibition found within Article 35(3) of Protocol I, ${ }^{37}$ but the authors penned an additional provision in Rule 44, such that:

Methods and means of warfare must be employed with due regard to the protection and preservation of the natural environment. In the conduct of military operations, all feasible precautions must be taken to avoid, and in any event to minimise, incidental damage to the environment. Lack of scientific certainty as to the effects on the environment of certain military operations does not absolve a party to the conflict from taking such precautions. ${ }^{38}$

Certainly, clauses two and three of Rule 44 can be deduced, to some extent, ${ }^{39}$ from state practice governing precautions in attack. And, as with the chosen

36 Negotiating states appeared to agree to the notion of 'long-term' being measured in 'decades, twenty or thirty years as a minimum'. See CDDH/215/Rev.1, para. 27; Y. Sandoz et al., above note 4, para. 1454.

37 The US rejects the Study's conclusion that Rule 45 reflects customary law, see letter dated November 3, 2006 written by John B. Bellinger III, Legal Adviser for the Department of State, and William J. Haynes II, General Counsel for the Department of Defense, to Jakob Kellenberger, President of the International Committee of the Red Cross, in International Review of the Red Cross, Vol. 89, No. 866, June 2007, p. 455. The Rule is described as lex ferenda by Major J. Jeremy Marsh, 'Lex Lata or Lex Ferenda? Rule 45 of the ICRC Study on Customary International Humanitarian Law', in Military Law Review, Vol. 198, 2008, pp. 116-164.

38 J. M. Henckaerts and L. Doswald-Beck, above note 2, Rule 44.

39 This partial criticism of the formulation as adopted relates specifically to the authors' recognition of the precautionary principle found in international environmental law, which this author believes is not reflected at the current time in international humanitarian law, and thus not in customary international humanitarian law; at least, not reflected in the form adopted by the authors. See Karen Hulme, 'Natural 
formulation of clause one of Rule 44, of course, the provisions governing precautions in attack (Article 57 of Protocol I) contain no threshold of harm. Article 57 refers instead to 'constant care' being taken to 'spare the civilian population, civilians and civilian objects'. Since this reference to 'sparing' civilian objects would appear to be closer to the meaning of clause two of Rule 44, is clause one then based to some degree on state practice of the 'care' obligation in Article 55(1) of Protocol I? And, if so, is this a fair reflection of state practice and thus a customary norm; and what are we to make of the glaring absentee - the threshold of harm?

While much of the wording of clause one of Rule $44^{40}$ is similar to that found within the 'care' obligation of Article 55(1), it is submitted that this is not the same creature. Leaving aside both the notion of 'preservation' that is more at home with marine protection ${ }^{41}$ and naval warfare, ${ }^{42}$ and the limitation in clause one only to the employment of means and methods (and not the broader notion of all 'warfare'), the key difference is in the notion of 'due regard to the protection' of the environment.

\section{The notion of 'due regard'}

The notion of 'due regard' is understood as involving a balancing exercise between two or more sets of rights or interests. ${ }^{43}$ It is found within the Law of the Sea Convention $^{44}$ and, consequently, in rules on naval warfare where warring states must take into account the rights of other seafarers and where such a balancing exercise is necessary. ${ }^{45}$ In this sense, then, the notion of 'due regard' seems to imply a more relative characteristic than that of 'care'. Furthermore, the 'regard' that is 'due' to the environment could quite conceivably be very low and have nothing to do with the prevention of environmental harm. Thus, it is submitted that Rule 44 of the Customary Law Study imposes an obligation requiring a balancing exercise in

environment', in Elizabeth Wilmshurst and Susan Breau (eds), Perspectives on the ICRC Study on Customary International Humanitarian Law, Cambridge University Press, Cambridge, 2007, pp. 204-237, at pp. 223-228.

40 This formulation is found with one wording change of 'should' from the US Naval Handbook to 'must' in Rule 44 of the Customary Law Study. See J. M. Henckaerts and L. Doswald-Beck, above note 2, Vol. II, Part 1, Ch. 14, p. 861, para. 81.

41 See 'United Nations Convention on the Law of the Sea of 10 December 1982' (hereafter UNCLOS), Art. 192, in International Legal Materials, Vol. 21, 1982, p. 1261.

42 See K. Hulme, above note 39, pp. 218-220.

43 See Louise Doswald-Beck (ed.), San Remo Manual on International Law Applicable to Armed Conflicts at Sea (hereafter San Remo Manual), prepared by international lawyers and naval experts convened by the International Institute of Humanitarian Law, International Institute of Humanitarian Law, Cambridge University Press, Cambridge, 1995, p. 84, para. 12.2. Rather confusingly, the San Remo Manual's provision on environmental protection is also numbered as Rule 44.

44 For example, see UNCLOS, above note 41, Arts. 27(4), 39(3)(a), 56(2), 58(3), 60(3), 66(3)(a), 79(5), $87(2), 142(1), 148$, and 234.

45 The phrase found in the Customary Law Study's Rule 44 is mirrored in Rules 34 and 35 of the San Remo Manual, above note 43, governing 'due regard' to the rights and interests of states in the exclusive economic zone and on the continental shelf. Here the protection and preservation of the marine environment is specifically listed as a factor to consider in the carrying out of hostile actions (San Remo Manual, Rule 34) and mine-laying (San Remo Manual, Rule 35) in those maritime zones. 
the use of means and methods involving the interests of the protection (and preservation) of the environment. It does not, therefore, seem specifically to state the requirement of 'taking steps', or of doing something in protecting the environment from harm-as does the 'care' obligation of Article 55(1) of Protocol I. As a result of this formulation, it is submitted, Rule 44 of the Customary Law Study acknowledges the recognition of a need to protect the environment but, unlike the 'care' obligation in Article 55(1) of Protocol I, it seems to remain quite vague about what states need to do in balancing that acknowledged need. Of course, this vagueness may well be a true reflection of state practice. One piece of 'regard' that would be 'due' anyway would involve the principle of distinction (and discriminate warfare), as well as the rule of proportionality and precautions demanded by Articles 57 and 58 of Protocol I. With the limiters in place in clause one of Rule 44 of the Customary Law Study, therefore, it is submitted that it is not in fact the same obligation as that found within the first sentence of Article 55(1) of Protocol I. ${ }^{46}$ It is also questionable how far clause one of Rule 44 of the Customary Law Study is truly a reflection of customary law. ${ }^{47}$

\section{Rule 44 and the missing threshold of harm}

Bearing these criticisms in mind, the real value in clause one of Rule 44 is the absence of a threshold of harm. According to that clause, states are required, in employing their means and methods, to have 'due regard' to the protection of the environment, no matter how small or low level that damage might be. Arguably, if the perceived level of damage is quite low, the regard 'due' will be equally low. Yet the balancing exercise may prove quite useful at higher levels of potential harm, but which are still at a level below the widespread, long-term and severe damage threshold for Protocol I. There is, however, no evidence of the specific formulation of clause one in the military manuals of states (outside the naval warfare context), whether party to Protocol I or not. Indeed, the manuals almost all refer to the three threshold terms that are, of course, the minimum that states parties must recognize. Positive evidence, therefore, for the absence of a threshold by way of military manuals is minimal. One interesting example, however, is provided by the Australian Defence Force Manual (1994), which stipulates that 'those responsible for planning and conducting military operations have a duty to ensure that the natural environment is protected' ${ }^{48}$ While the Manual does later refer to the threshold in terms of the Article 55(1) prohibition on means and methods ${ }^{49}$ in this quote it notably imposes an obligation of result ('to ensure') while at the same time deleting any reference to the threshold of damage needed to activate the behalf of the International Committee of the Red Cross', in British Year Book of International Law, Vol. 76, 2005, p. 515, 'there is little, if any, precedent for [Rule 44] in existing law'.

48 J. M. Henckaerts and L. Doswald-Beck, above note 2, Vol. II, Part 1, Ch. 14, p. 861, para. 79.

49 Ibid., p. 880, para. 165. 
requirement of protection. This formulation certainly appears to be much more robust than that found in the 'care' obligation of Article 55(1). Whether wider state practice reflects this sense of a broader, higher level of 'duty' is doubtful though, at least in customary hard law form. Consequently, the absence of the threshold from Rule 44 of the Customary Law Study seemingly does not simply suggest that, even if that Rule were widely endorsed, the majority of states are ready to delete the threshold from the opening sentence of Article 55(1).

\section{The relationship with Articles 57 and 58 of Protocol I}

In bringing the two obligations ('due regard' and precautions) together in the one rule the Customary Law Study makes an interesting linkage. Of course, as one of the

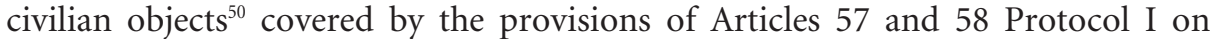
precautions, states are under the higher obligation of 'constant care' to 'spare' the environment in military operations in Article 57(1) Protocol I. And since the obligation in Article 57(1) Protocol I of taking care to 'spare' the environment, as a prima facie civilian object, is also an obligation of conduct there would appear to be an obvious overlap with the 'care' obligation in Article 55(1) Protocol I, but, of course, absent the very high threshold of damage. Arguably, since similar types of actions could fall within the notion of 'sparing' the environment as those under the 'care' obligation, notably avoiding, reducing or minimizing environmental damage, Article 57(1) Protocol I has real value for the environment.

As with the 'care' sentence in Article 55(1) Protocol I, the view of Article 57(1) Protocol I as enshrining only the 'general principle ${ }^{51}$ of sparing civilians and civilian objects tends to limit its potency as a real limit on military actions. The more concrete obligations of precaution are developed in the remainder of Article 57 and Article 58; but these clauses do not provide much for the environment beyond reminding states of the need for a robust application of the rules of distinction and proportionality. ${ }^{52}$ At most, an advance warning to the opposing party (required by Article 57(2)(c) Protocol I) could allow it the time to move military objectives from the location of an important environmental space, or put some protective facility in place (for example, relocating samples of rare or endangered species similar to what a state might do with cultural property)..$^{53}$ The real tragedy of the environment in warfare is due to its very nature as forming our surroundings, and so it cannot easily be relocated or warned away from the planned area of attack. ${ }^{54}$ On the other hand, one commitment that does appear to have real

50 When the environment does not fulfil the requirements of a military objective in Article 52(2) Protocol I.

51 Y. Sandoz et al., above note 4, para. 2191.

52 See Article 57(2)(a) and (b) Protocol I.

53 See Article 58(c) Protocol I requiring the (defending) party to take 'other necessary precautions to protect ... civilian objects under their control against the dangers resulting from military operations'.

54 See also Article 58(a) Protocol I on removing civilian objects, inter alia, from the vicinity of military objectives. 
environmental value, and is also suggested to fall within the 'care' obligation (above), is Article 57(3) Protocol I which requires the parties to choose the attack with least danger to civilians and civilian objects when such a choice exists.

\section{'Caring' versus 'Sparing'}

Consequently, while the 'care' obligation and the precautions provisions in Protocol I certainly do cover some of the same ground, the real value of the former is that it is specific to protection of the environment. An obligation to 'spare' the environment, it is submitted, is not as broad and robust, nor indeed emotive, as the obligation to 'protect the environment' against damage. It is furthermore submitted, that while some official statements of states appear to recognize the value of the environment and the need to protect the environment in wartime without reference to a threshold of harm, ${ }^{55}$ that such an approach might be unworkable in practice and even undesirable. Even if the de minimis peacetime threshold of 'not insignificant' harm were adopted in armed conflict, such a low threshold would not necessarily entail meaningful protection in practice. Such a low threshold of environmental damage might actually encourage states to adopt the simple tick box approach, previously dismissed as inadequate for real environmental consideration during armed conflict. It is not as perverse as it might at first appear then, but there is an argument for imposing a threshold of environmental damage in the 'care' obligation.

Arguably, therefore, with further discussion and elaboration the 'care' obligation could conceivably achieve widespread recognition as a real curb on environmentally-damaging warfare and a real gem for environmental protection. It has to be admitted, though, that at present much of this influence is still an aspiration. With little downward movement of the very high threshold of harm the 'care' obligation is severely limited, in hard law terms, in what it can achieve. Furthermore, to suggest the removal of the threshold completely could impose far too high a burden on states, if the 'steps' required were to have real meaning that is. Certainly, its replacement with a lower threshold such as 'significant' harm would be less objectionable; but such a change remains highly unlikely without a radical rethinking in this area of the law. What then is the worth of the 'care' obligation?

\section{Daring to care}

With little prospect of a hard law shift in the immediate future it should at least be recognized that the obligation to 'take care to protect the environment' in Article

55 See for example comments made in submissions to the International Court of Justice in the Nuclear Weapons Case, as quoted in J. M. Henckaerts and L. Doswald-Beck, above note 2, Vol. II, Part 1, Chapter 14, notably Sri Lanka at p. 866, para. 104, Qatar at p. 865, para. 102, Malaysia at p. 865, para. 97, and Egypt at p. 862, para. 88 . 
55(1) Protocol I continues to shine like a beacon to encourage states to value the environment during armed conflict. And this role should not be understated. Even with the inclusion of the threshold the obligation to 'take care' requires states to, at least, contemplate what environmental damage might be caused by their military operations and just how serious a level of harm is foreseeable. Indeed, this general principle of environmental protection in warfare is clear to see in the actions of states: for example, a number of states have abandoned depleted uranium weapons altogether or switched to the so-called greener alternative, notably tungsten, ${ }^{56}$ the US has introduced carbon-cutting measures on its domestic military bases, ${ }^{57}$ and, of course, following widespread state condemnation of Iraqi destruction of oil wells in the first Gulf Conflict (1991) the Security Council readily included compensation for environmental clean-up efforts. ${ }^{58}$ In recent years states' concern for the environment in wartime has also translated into frequent attention by the Security Council and General Assembly, as well as a plethora of UN bodies and nongovernmental organizations. ${ }^{59}$ Finally, according to Schmitt, that environmental protection was not deemed too controversial to be included within the 1998 Rome Statute of the International Criminal Court 'attests to the extent which environmental damage during armed conflict has entered the normative conscience of humanitarian law'. ${ }^{60}$ Whether these and other examples of state action are responses to a perceived hard law obligation, soft law principle, or even a mere policy decision, there is undoubtedly a great deal of evidence to suggest that armed conflict is becoming more environmentally friendly, even if the laws themselves are slow to adapt. What does this mean in reality?

It is submitted that although states are generally not keen to negotiate new (jus in bello) environmental regulations, their actions in fact tend to demonstrate an awareness and enthusiasm for environmental protection during armed conflict. In other words, the hard law minimum that many states are willing officially to recognize, is only the starting point; their policies of environmental protection and the avoidance of environmental harm achieve so much more in practice and this point should be acknowledged. Thus hopefully very soon states may reach the point at which they are keen to reduce the very high threefold threshold of the

56 It is questionable, however, how much greener tungsten really is.

57 See David Sheets, 'Military Technology and Renewable Energy', in Carolyn Pumphrey, Global Climate Change National Security Implications, Strategic Studies Institute, 2008, available at: http://www. strategicstudiesinstitute.army.mil/pubs/display.cfm?PubID=862 (last visited 20 September 2010).

58 See Security Council Resolution 687 (1991) of 3 April 1991.

59 See, for example, General Assembly Resolution 61/154 of 19 December 2006, 'The human rights situation arising from the recent Israeli military operations in Lebanon'; General Assembly Resolution 62/ 188 of 19 December 2007, 'Oil slick on Lebanese shores'; General Assembly Resolution 62/30 of 5 December 2006, 'Effects of the use of armaments and ammunitions containing depleted uranium'; ICRC, '1994 Revised Guidelines for Military Manuals and Instructions on the Protection of the Environment in Times of Armed Conflict', in International Review of the Red Cross, Vol. 30, No. 311, 1996, pp. 230-237, and the work of the UNEP Post-Conflict Assessment Unit, available at: http:// www.unep.org/depi/programmes/post_conflict_assessment.html (last visited 20 September 2010).

60 See Michael N. Schmitt, 'Humanitarian Law and the Environment', in Denver Journal of International Law and Policy, Vol. 28, 2000, p. 284. 
'care' obligation in Article 55(1) Protocol I to a more valuable level of say 'significant' or 'serious' harm.

In addition, while at present the text of the 'care' obligation in Article 55(1) Protocol I is confined to 'warfare', states appear to be generally amenable to a broader interpretation of environmental 'care' in practice. Considered application of the 'care' provision, therefore, may be valuable in helping to protect the wartime environment against threats not confined simply to means and methods, such as curbing the environmentally-destructive exploitation of conflict resources ${ }^{61}$ (including in non-international armed conflict ${ }^{62}$ ), as well as addressing the contribution of warfare to climate change and its potential impacts. It is also in the obligation of 'care' that one could possibly foresee an international humanitarian law usage or adoption of a principle of precautionary action, mirroring that found in environmental law, with particular applicability for actions, weapons or techniques with potentially serious levels of environmental damage but which has yet to be sufficiently scientifically proven. ${ }^{63}$

\section{Conclusions}

After undertaking an interpretation of the obligation of 'care' for Article 55(1) Protocol I it is submitted that this 'care clause' is not simply stating the 'underlying concept $^{34}$ or the general principle recognizing the need for environmental protection in armed conflict. The treaty provision extends beyond mere hortatory expression or aspiration; it requires real action by states parties to take steps to protect the environment against damage. Unfortunately, the same high threshold of harm is included here as is found in Article 35(3) Protocol I which masks here, as there, the true value of the obligation. Consequently, states parties are required to take steps to protect the environment only against damage that is perceived to breach the threshold of widespread, long-term and severe harm. With little downward movement in the threshold it seems that the 'care' provision is denied real meaning in hard law terms. It is not true, however, that the provision is without meaning altogether. States parties will, at the very least, need to undertake an assessment of potential environmental impacts of their proposed actions in

61 See Global Witness, The Sinews of War: Eliminating the Trade in Conflict Resources, Briefing Document, 2006, available at: http://www.globalwitness.org/media_library_detail.php/480/en/the_sinews_of_war (last visited 20 September 2010); and United Nations Environment Programme, Protecting the Environment During Armed Conflict: An Inventory and Analysis of International Law, November 2009, available at: http://www.unep.org/PDF/dmb/ProtectEnvDuringConflict_en.pdf (last visited 20 September 2010).

62 Note the inclusion of an obligation of 'regard' to the environment in internal armed conflict in the UK Military Manual. See United Kingdom Ministry of Defence, Manual of the Law of Armed Conflict, Oxford University Press, Oxford, 2004, para. 15.20.

63 Some interesting thoughts on a precautionary approach are included in Avril McDonald, Jann K. Kleffner and Brigit Toebes (eds), Depleted Uranium Weapons and International Law: A Precautionary Approach, T.M.C. Asser Press, 2008.

64 Y. Dinstein, above note 6. 
order to comply with this as well as other provisions of Protocol I. And states can and do choose to take steps to protect the environment for lower levels of perceived harm. The US is itself an example of a state not treaty bound by Protocol I but which often chooses to reflect principles of environmental protection in public statements explaining its military actions.

While the Customary Law Study's Rule 44 appears similar in some respects to the 'care' provision in Article 55(1) Protocol I, it is submitted that it is not the same obligation. Consequently, the absence of the threshold from Rule 44 of the Customary Law Study could not, even if Rule 44 were widely endorsed, simply suggest that states are ready to delete the threshold from Article 55(1) Protocol I. Indeed, it is submitted that customary law at the present time does not reflect this sentiment. It is further submitted that such an obligation while potentially workable, would possibly impose far too high a burden to be acceptable to states if those 'steps' were to have real meaning.

The sentiment of environmental protection found in the 'care' obligation is also undoubtedly present in states generally in wartime and emanates from the peacetime recognition of the value of the environment to mankind. And it is this recognition of the value of the environment, not only a healthy but ecologicallyviable environment, together with the recognition of the environment as a prima facie civilian object that have been consistently and positively influencing the military actions of states during the recent past.

Finally, if states are encouraged to consider the 'care' obligation in this way the provision may also prove valuable in protecting the wartime environment from all sorts of threats, not only from the poisonous impacts of collateral damage from pharmaceutical or chemical factories, but from the destruction and exploitation of conflict resources (in internal armed conflict if the provision were to gain a customary equivalent), and the polluting effects of certain weapons. Considered application of the 'care' provision may also be valuable in preventing military actions exacerbating the onset or impacts of climate change: a pertinent issue in contemporary international law. 